\title{
Editorial: LITA and ITAL: Forty and Still Counting
}

B y now, most Library and Information Technology Association (LITA) members and Information Technology and Libraries (ITAL) readers know that 2006 is the fortieth anniversary of LITA's predecessor, the Information Science and Automation Division (ISAD) of the American Library Association (ALA). And 2007 marks the fortieth birthday of ITAL, first published in 1967 as the Journal of Library Automation (JOLA). I hope that members and readers know the vital role played by Fred Kilgour in the founding of the division and as $J O L A$ 's founding editor.

This issue marks the initiation of a two-volume celebration (volumes 25 and 26) of his role as founding editor by publishing what we hope are significant articles resulting from original research, the development of important and creative new systems, or explications of significant new technologies that will shape future information technologies. I have invited some of the authors of these articles to submit their manuscripts. Others are being submitted in response to a call I published both in an earlier editorial and in a message to the lita-1 discussion list. Whether invited or submitted, they will receive the same double-blind refereeing that all ITAL articles undergo. The referees will not know which articles have been invited or submitted for this purpose. The articles will, however, be so designated when they are published.

Volume 25 initiates a second landmark for ITAL. Henceforth, ITAL will be published simultaneously in electronic and print versions. The electronic copy will be available to LITA members and ITAL subscribers on the ALA/LITA Web site. Equally significantly, at the 2006 ALA Midwinter Meeting in San Antonio, the LITA board of directors approved a second proposal from the LITA Publications Committee. (The ITAL editor and editorial board report to the publications committee.) After six months, the electronic issues will be open to all, not restricted to members and subscribers.

Put simply, if you are a member or subscriber reading this issue in print, you may also read it and volume 25, number 1 (the March 2006 issue) on the Web. When volume 25, number 3 is published in September 2006, the March issue on the Web will be open for anyone to read. When the December issue is published, this June e-issue will be open to all.

The Web versions are to be published in both PDF and $\mathrm{html}$ versions. Most ITAL articles now include URLs. Readers will be able to link to them. Most figures and graphs submitted by authors are in color. From now on, these will be available to the readers of the e-copies.

ALA publishing allows authors to submit their articles to institutional repositories, and many authors now do so. Authors will retain this option. Some articles have been posted on other portals as well. Martha Yee's outstanding June 2005 article on how to FRBRize the OPAC appears not only on UCLA's repository site but also on the eScholarship Repository site of the University of California system, one of the few library-related articles on the site (http://repositories.cdlib.org/escholarhip). Furthermore, on November 29, 2005, it was among the top ten most popular articles on the site. Recently, dLIST (http:/ / dlist.sir.arizona.edu) at the University of Arizona Library received permission to include it.

The decisions to allow simultaneous publication of print and electronic versions and to allow open access after six months were not made lightly. The LITA board members carried on extensive electronic discussions among themselves and with Nancy Colyar, chair of the publications committee, and me. LITA president Pat Mullin's summary of those discussions was more than ten single-spaced pages. Nancy and I also attended a meeting of the board in San Antonio. Publications and memberships are two chief sources of revenue for almost all professional associations. In two surveys in the past ten years, LITA members have indicated they considered ITAL to be their most important membership benefit. LITA membership fell this year, probably because of the recent dues increases by other divisions of ALA. This decline was anticipated by LITA's leadership.

I think both the ITAL editorial board and the LITA leadership would love to take the additional pioneering step of making our journal a full open-access publication. However, legitimate concern was expressed that opening access after six months might lead to both a decrease in members and subscribers. A significant number of LITA leaders said that their membership was based on LITA programs, participation, and interaction with colleagues, not just ITAL. I hope that all LITA members feel the same. I further hope that LITA members will do everything they can to discourage their libraries from canceling their subscriptions. Our financial health would be enhanced if all LITA members took two other steps: participating in writing and encouraging the writing of significant articles, and encouraging your many library technology vendors to advertise in ITAL.

Fred Kilgour and the other founders of our division were library information technology (IT) pioneers. Fred's leadership helped make JOLA and now ITAL vital reading for library IT professionals. I believe that by celebrating the LITA/ITAL anniversaries with a reconfirmation of our practice of publishing articles of the highest quality and by making ITAL more accessible through electronic publication, we are reaffirming the scholarly and professional commitments first made by Fred Kilgour and his ISAD colleagues such a short forty years ago.

John Webb (jwebb@ wsu.edu) is Assistant Director for Systems and Planning, Washington State University Libraries, Pullman, and Editor of Information Technology and Libraries. 